\title{
Menanamkan Nilai Kesabaran di dalam Keluarga Pada Masa Pandemi Covid-19
}

\author{
Ernida Marbun \\ Sekolah Tinggi Teologi Sumatera Utara \\ ernidaerni81@gmail.com
}

\begin{abstract}
This article describes strategies to instill the value of patience in families during the Covid-19 Pandemic. This is very necessary because during the Covid-19 pandemic there was a problem of impatience between family members. The strategy of cultivating the value of patience is of course carried out with a Christian religious education approach in the family, meaning that the values of patience are taught by parents to their children. This article describes a problem-solving strategy based on John 15: 1-10, imitating Jesus' teaching to the disciples to be patient with the problems they will face in the future. The goal is that family members during the Covid-19 pandemic will continue to live patiently in Christ. The method used in this research is a qualitative method with a descriptive approach.
\end{abstract}

Keywords: the value of patience; Christian family education; covid-19 pandemic

Abstrak: Artikel ini menjelaskan tentang strategi menanamkan nilai kesabaran dalam keluarga di masa pandemi Covid-19. Hal ini sangat diperlukan karena pada masa pandemi covid-19 ini di dalam keluarga terjadi masalah ketidaksabaran antara anggota keluarga. Strategi penanaman nilai kesabaran tersebut tentunya dilakukan dengan pendekatan pendidikan agama Kristen di dalam keluarga artinya nilai-nilai kesabaran tersebut diajarkan oleh orang tua kepada anakanaknya. Artikel ini memaparkan strategi pemecahan masalah berdasarkan Yohanes 15:1-10, meneladani pengajaran Yesus kepada murid-murid supaya sabar menghadapi persoalan yang akan mereka hadapi kedepan. Tujuannya supaya anggota keluarga dalam masa pandemi Covid19 ini tetap tinggal dengan sabar di dalam Kristus. Penelitian ini mengunakan metode kualitatif dengan mendeskripsikan hasilnya.

Kata kunci: Nilai kesabaran; pendidikan keluarga Kristen; pandemi covid-19

\section{Pendahuluan}

Kehidupan manusia berubah total dampak dari Pandemi Covid-19. Semua tatanan dalam kehidupan manusia berubah masyarakat Indonesia karena, "adanya aturan 
tentang menjaga jarak untuk mengatasi dan mengendalikan Virus Corona"1 Di Indonesia terhitung mulai tanggal 2 Maret 2020 sampai 9 Maret 2021 sebanyak 1.379 .662 terkena virus, 37.266 orang meninggal dan sembuh 1.194 .656 orang. $^{2}$ Pemerintah mengerakkan $5 \mathrm{M}^{3}$, sehingga pada saat masyarakat harus menerapkan $5 \mathrm{M}$ tidak dapat secara leluasa bekerja, sekolah dan melaksanakan kegiatan seperti pada saat sebelum ada pandemi. Perubahan tersebut membuat masyarakat harus mengubah kebiasaan-kebiasaannya yang sudah biasa dijalaninya hal ini membuat orang-orang memiliki perilaku tidak sabar. Perilaku ketidaksabaran membuat meningkatnya stress masyarakat. Julianan dalam surat kabar menuliskan perilaku tidak sabar tersebutlah membuat beberapa orang bunuh diri, perkelahian dan menurunnya produktivitas kerja. WHO memprediksi bahwa pada tahun 2021 akibat ketidaksabaran akan ada tindakan bunuh diri sebanyak 2,4 per 100.000 jiwa. $^{4}$

Untuk mengatasi kecemasan tersebut maka sangat diperlukan menanamkan kesabaran kepada semua anggota keluarga supaya mereka dapat menghadapai kondisi pandemi yang terus berkelanjutan ini dengan sabar. Nilai kesabaran yang terutama ditanamkan di tengah-tengah keluarga sebagai unit terkecil dalam masyarakat ${ }^{5}$. Pada saat anggota-anggota keluarga dapat menjalankan kehidupan dengan sabar menghadapi keadaan pandemi Covid-19 ini maka akan berdampak kepada kesabaran masyarakat. Nilai kesabaran didapatkan dari hasil iman kita kepada Firman Tuhan, untuk itu nilainilai kesabaran tersebut dianalisa dari Yohanes 15:1-10 dan nilai-nilai tersebut akan ditanamkan kepada anggota keluarga khususnya kepada anak-anak oleh orang tua ${ }^{6}$.

Nilai kesabaran dapat ditanamkan di dalam diri anggota keluarga sejak usia dini supaya di masa tuanya nilai itu tetap akan menjadi sifat anggota keluarga tersebut. Orang tua harus menjadi teladan supaya dicontoh oleh anak-anak dalam menghadapi persoalan kehidupan dengan sabar serta juga mengajari anak-anak untuk hidup sabar. Pada saat seorang anggota keluarga memiliki sifat sabar maka dia dapat menjadi saksi bagi orang lain. ${ }^{7}$ Orang tua secara sederhana mensosialisasikan kepada anak-anak mereka nilai-nilai kekristenan itu melalui kehidupan mereka. Anak-anak meneladani sikap, karakter dan tindakan orang tua serta menerima pengajaran di dalam pendidikan agama Kristen dalam keluarga, dalam persekutuan keluarga belajar tentang nilai-nilai kehidupan sebagai orang Kristen ${ }^{8}$ Groome mengemukakan bahwa sosialisasi Kristen di dalam keluarga penuh dengan kemesraan dan kasih. Di dalam keluarga anak-anak terbentuk identitasnya sebagai orang yang sabar, penuh kasih, sukacita dan damai

\footnotetext{
${ }^{1}$ Permenkes RI Nomor 10 Tahun 2021

${ }^{2}$ Aditya Budiman, Update Covid-19 per 7 Maret 2021

${ }^{3}$ Tamara Anastasia, Mau Pandemi Usai? Ketahui Pentingnya Gerakan 5M COVID-19.

${ }^{4}$ Ida F S, Kebersyukuran : Suatu Upaya Membangun Karakter Bangsa, (https://media.neliti.com/media/publications/76271-ID-kebersyukuran-upaya-membangu)

${ }^{5}$ Maurice Eminyan, SJ, Dogma Keluarga (Yogyakarta: Kanisius, 2001), 23

${ }^{6}$ Homrighausen dan I. H. Enklaar, PAK, (Jakarta: BPK Gunung Mulia, 1984), 144.

${ }^{7}$ N. K. Atmadja Hadinoto, Percakapan dan Pendidikan, (Jakarta: BPK GM, 2000), 191

${ }^{8} \mathrm{Ibid}, 184$.
} 
sejahtera. ${ }^{9}$ Hal menanam nilai kesabaran ini sudah sangat urgen karena sebelum masa pandemi Covid 19 anak-anak masih dapat bermain dan belajar dengan bebas, tetapi di masa pandemi Covid-19 ini sudah sangat terbatas sehingga tingkat stress anak-anak sangat tinggi. Jadi, di dalam penelitian ini akan dianalisa aspek-aspek dari nilai kesabaran berdasarkan Yohanes 15:1-10 dan bagaimana orang tua memakai pendidikan agama Kristen untuk menanamkan nilai kesabaran bagi anak-anak mereka.

\section{Metode Penelitian}

Berdasarkan masalah penelitian di atas maka metode penelitian kualitatif dengan pendekatan deskriptif. ${ }^{10}$ Moleong menjelaskan bahwa data yang dikumpulkan dalam pendekatan deskriptif sebagai hal yang penting apa yang sedang diteliti. Selain itu, dalam pendekatan deskriptif, peneliti tidak akan memandang bahwa hal-hal yang diamati itu memang demikian adanya. ${ }^{11}$ Adapun proses penelitian yang dilakukan oleh peneliti ialah mengamati pentingnya menanamkan nilai kesabaran dalam masa pandemi Covid-19 dibahas dengan mengamati fakta empiris. Kemudian melakukan identifikasi masalah. Setelah itu, peneliti menganalisa Yohanes 5:1-10 untuk menemukan aspekaspek dari nilai kesabaran untuk ditanamkan dan selanjutnya mendeskripsikan cara penanaman nilai kesabaran tersebut. Menyajikan hasil penelitian tersebut dengan sistematis.

\section{Hasil dan Pembahasan}

\section{Hakekat Nilai Kesabaran dalam Perspektif Yohanes 5:1-10}

Nilai kesabaran adalah salah satu dari nilai-nilai Kristiani yang harus dimiliki oleh orang percaya pada masa pandemi ini. Aspek-aspek nilai kesabaran akan dianalisa dari pengajaran Yesus melalui perumpamaan pokok Anggur yang benar. Metode pengajaran lewat perumpamaan merupakan salah satu cara Yesus untuk menyampaikan ajarannya. Di dalam Yohanes 15 Yesus menyampaikan pokok utamanya supaya muridmurid tetap tinggal di dalam Yesus untuk menghasilkan buah. ${ }^{12}$ Di dalam Alkitab ada minimal dua buah yang dihasilkan dalam hidup orang percaya yaitu buah roh dan buah pelayanan yaitu murid-murid. di dalam Yohanes 15 ini buah yang dimaksudkan adalah buah kehidupan pada saat kita tinggal di dalam Kristus baik buah perubahan karakter dan buah pelayanan. ${ }^{13}$ Stephen Tong menyatakan bahwa,"Buah Roh Kudus di dalam Galatia 5:22 di dalam bahasa aslinya hanya kasih dan bahasa Inggris kata buah dalam bentuk tunggal The only fruit of the Holy Spirit. Buah itu memiliki sembilan nilai salah

\footnotetext{
${ }^{9}$ Thomas H. Groome, Christian Religious Education, (Jakarta: BPK Gunung Mulia, 2010), 53.

${ }^{10}$ M. Djunadi dan Fauzan Almanshur, Metode Penelitian Kualitatif, (Yogyakarta: Ar-Ruzz Media, 2012), 28.

${ }^{11}$ Lexy J. Moleong, Metodologi Penelitian Kualitatif (Bandung: Remaja Rosdakarya, 2018), 11.

${ }^{12}$ Hasan Sutanto, Hermeneutik: Prinsip dan Metode Penafsiran Alkitab,(Malang: Literatur SAAT, 2007), 34

${ }^{13}$ Budi Asali, Eksposisi Yohanes 15, (Jakarta: Golgota Ministry, 2016), 78
} 
satunya adalah kesabaran. ${ }^{14}$ Jadi sangat relevan jika dijadikan Yohanes sebagai sumber utama untuk melihat nilai kesabaran.

Kata "kesabaran" bersumber dari kata makrothumia dari kata marcos artinya panjang dan thumos yang artinya karakter yang artinya memiliki karakter yang tabah, sabar dan tahan menghadapi penderitaan. Kata makrothumia ini juga berarti sanggup untuk menangung penganiayaan dan kekejaman. Walaupun ada waktu untuk membalas dendam, tetapi tetap sabar. Dalam KUBI, "kata sabar artinya siap menjalani cobaan, tidak emosi, tidak lesu dan tak bersemangat, lebih tenang, tak gegabah" ${ }^{15}$ Jadi, sabar artinya mampu menangung penderitaan, tidak gegabah dan tetap bersemangat.

Kesabaran ini merupakan sifat Allah, dimana Allah menahan murka-Nya walaupun kita masih berdosa. Sifat sabar ini selalu berkaitan dengan sifat kasih dan anugrah-Nya kepada yang berdosa dan layak dihukum". ${ }^{16}$ Nilai kesabaran ini akan kita miliki apa bila kita tinggal di dalam Kristus atau kita dipenuhi oleh Roh Kudus. ${ }^{17}$ "Kita harus tetap tinggal di dalam Keritus supaya nilai kesabaran yang merupakan sifat Kristus tetap tinggal di dalam Kita". ${ }^{18}$ Simamora dan Hasugian mengutip pendapat Reich dan Gray bahwa nilai kesabaran akan terus berkelanjutan (sustainability), di dalam diri seseorang sehingga orang itu mampu untuk menjalani hidup yang dengan tenang". 19 Jadi nilai kesabaran ini ada di dalam diri kita apabila kita tinggal di dalam Kristus, supaya kita tinggal di dalam Kristus maka di dalam Yohanes 15:1-10 ditemukan empat aspek yang menghasilkan nilai kesabaran tersebut dalam diri kita.

Pertama, Berakar dalam Firman Tuhan. Yohanes menyatakan bahwa Firman Tuhan harus tinggal di dalam kita. Kata tinggal di dalam Firman dalam perumpamaan Pokok Anggur yang benar sama pengertiannya dengan berakar di dalam Firman seperti yang dikatakan oleh Paulus:" Hendaklah kamu berakar di dalam Dia"20. Kata berakar dalam bahasa aslinya errizomenoi artinya telah diakarkan, pemakaian kata ini dalam bentuk kata kerja perfect pasif yang artinya Firman Tuhan itu bekerja secara sempurna di dalam diri seseorang sehingga Firman itu melahirkan nilai kesabaran dalam diri orang itu.

Di dalam Perjanjian Lama, seorang tokoh yang sabar adalah Abaraham. Abraham tetap konsisten kepada janji Firman Tuhan dalam apapun yang mereka hadapi. Abraham berulangkali diuji tetapi ia tetap sabar kepada Firman yang dijanjikan Allah

\footnotetext{
${ }^{14}$ Stephen Tong, Hidup Kristen Yang Berbuah, (Jakarta: GRII, 2016), 78

15“'Sabar"; KBBI. Versi 1.1 CD-Rom

${ }^{16}$ Ensiklopedi Alkitab Masa Kini Jilid II(Jakarta: Yayasan Komunikasi Bina Kasih, 2008), 335.

${ }^{17}$ Enns, Paul., 2004. The Moody Handbook of Theology, jilid 2. Terjemahan, Penerbit Literatur SAAT : Malang, 229-241.

${ }^{18}$ Boa, Kenneth, Sid Buzzell \& Bill Perkins, Handbook To Leadership, terj. Penerbit Yayasan Komunikasi Bina Kasih: Jakarta, 2013, 18.

${ }^{19}$ May Rauli Simamora, Johanes Waldes Hasugian, Penanaman Nilai-nilai Kristiani bagi Ketahanan Keluarga di Era Disrupsi (Jurnal: Regula Fideil Jurnal pendidikan Agama Kristen, 2020), 1324

${ }^{20}$ Kolose 2:7a
} 
bahwa dia akan menjadi bangsa yang besar"21. Di dalam PB, kita dapat melihat Maria merupakan salah satu orang yang berakar di dalam Firman Tuhan sehingga pada saat Maria menerima amanat dari Allah sebagai ibu insani Yesus ia berkata: Sesungguhnya, aku ini adalah hamba Tuhan. Jadilah padaku menurut perkataan-Mu (Firman-Mu) itu. Kata sesungguhnya dalam bahasa Yunani adalah idou, yang jika diterjemahkan berarti behold atau truly. Maria secara sadar menerima konsekuensi sebagai hamba Tuhan sehingga dia dengan sabar menerima amanat tersebut walaupun ada resiko yang harus diterima". 22 Paulus berkata kepada jemaat Korintus untuk tetap teguh, jangan goyah berpegang kepada Firman Tuhan meneladani Yesus yang tetap setia kepada Kehendak Allah." 23 Yesus juga menyatakan bahwa menjadi murid Yesus harus menyangkal diri, memikul salib dan mengikut Yesus, jika kita tidak bisa melakukan itu kita tidak layak menjadi murid Yesus. Jadi, seseorang yang sabar apabila hidupnya berakar di dalam Firman Tuhan.

Pada masa pandemi ini orang percaya juga harus berakar di dalam Firman Di masa pedemi Covid-19 ini pasti ada tantangan besar tetapi kita tetap memegang Firman Tuhan. Petrus berkata ,"Apakah kami harus lebih takut kepada manusia daripada Allah"24 ketika Petrus diperhadapkan kepada penganiayaan di Yerusalem. Di dalam Perjanjian Lama, Yusuf lari dari godaan istri Potifar menunjukkan ia tetap konsisten kepada Firman walaupun berulangkali digoda oleh istri Potifar. Itu sebabnya pemazmur berkata:"dengan apakah seorang muda menjaga kelakuannya bersih dengan menjaganya sesuai Firman Tuhan". Kekonsistenan seseorang berpegang teguh kepada Firman ditunjukkan oleh saksi-saksi iman di kitab Ibrani. "Lihatlah akhir hidup mereka" menunjukkan bahwa mereka konsisten berpegang kepada Firman sampai akhir hidup mereka.

Cara kita tetap tinggal di dalam Firman dengan cara membaca Firman, mempelajari firman, menghafal firman, merenungkan firman dan melakukan Firman. ${ }^{25}$ Keempat tindakan tersebut merupakan cara kita menanamkan Firman dalam keluarga. Orang tua harus menjadi teladan dalam melakukan kelima hal di atas dengan disiplin dan juga mengajarkan kepada anak-anak mereka dengan disiplin. Orang yang membaca, mempelajari, menghafal, merenungkan dan melakukan Firman Tuhan akan membuat Firman itu tinggal dalam diri orang itu. Membaca, mempelajari, menghafal, merenungkan dan melakukan Firman harus dilakukan secara konsisten dan dilakukan dengan penuh kedisiplinan. Kata disiplin memiliki akar kata yang sama dengan murid

\footnotetext{
${ }^{21}$ Seri Damarwan, Nilai Kesempurnaan Kristen Dalam Kitab Ibrani, Jurnal Teologi Sanctum Domine, (Article Text-97-1-10-20191212.pdf)

${ }^{22}$ Herlise Yetty Sagala, Aku ini adalah Hamba Tuhan, Bandung: STTB http://www.sttb.ac.id/informasi/artikel/441-aku-ini-adalah-hamba-tuhan

${ }^{23}$ Handreas Hartono, Membentuk Karakter Kristen Pada Anak Keluarga Kristen, Jurnal Teologi dan Pendidikan Agama Kristen KURIOS, Vol. 2, No.1, Oktober2014(62-69)ISSN 2406-8306.

${ }^{24}$ Kisah Pra Rasul 2:43

${ }^{25}$ Kevin, Kehidupan Anda Di Dalam Kristus (Jakarta:BPK Gunung Mulia, 2018), 34
} 
(disciple) yang artinya seseorang yang siap berakar kepada Firman secara konsisten dan diarahkan pada saat menyimpang dari Firman Tuhan"26.

Di dalam Perjanjian Lama, pada waktu pergantian kepemimpinan dari Musa kepada Yosua, Musa menasehati muridnya untuk disiplin tidak menyimpang ke kiri dan kanan supaya perjalananmu berhasil. Anggota jemaat harus disiplin di dalam belajar Firman Tuhan supaya jemaat memiliki pikiran Kristus dalam melayani Tuhan. ${ }^{27}$ Disiplin tersebut untuk melatih anggota keluarga sehingga semua anak-anak hidup sesuai Firman. ${ }^{28}$ Paulus juga memberikan analogi sebagai murid harus seperti prajurit. Dua sifat perajurit yang paling menonjol adalah siap berkorban dan disiplin. Anggota keluarga harus secara disiplin membaca, mempelajari, menghafal, merenungkan dan melakukan Firman Tuhan sehingga Firman Tuhan itu tinggal di dalam diri anak-anak kita dan kita menghasilkan nilai kesabaran. Jadi, nilai kesabaran ditujukan oleh anggota keluarga dengan hidup yang berakar di dalam Firman secara konsisten dan siap diarahkan pada waktu menyimpang dari Firman Tuhan di masa pandemi covid-19 ini.

Kedua, Beriman Teguh. Yohanes berkata tentang mengasihi Tuhan apabila menuruti perintah Allah. Kata "menuruti" dalam bahasa Yunani adalah tereo, artiya beriman teguh kepada Firman. Kehidupan orang percaya yang berakar pada Firman Tuhan melahirkan iman yang teguh. Iman timbul dari pendengaran akan Firman Tuhan, iman berfungsi sebagai perisai untuk menghadapi semua masalah yang dijadikan iblis untuk menjadi panah api kepada kita untuk mematikan iman kita. Pandemi Covid-19 dapat menjadi senjata iblis untuk mematikan kerohanian kita apabila kita tidak memiliki perisai iman. Perisai iman inilah membuat kita tidak mudah menyerah sebagai nilai kesabaran dalam menghadapi situasi apapun. Orang percaya harus beriman teguh kepada janji pemeliharaan Allah. Iman yang teguh akan menjadi perisai sehingga tidak ada rasa putus asa walaupun ada tantangan besar yang terjadi.

Bangsa Israel yang sedang menghadapi tantangan berat di Babilonia melalui nabi Yeremia Allah berjanji bahwa bangsa itu akan memperoleh masa depan yang penuh

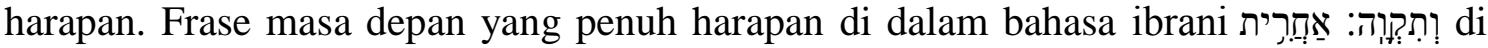
dalam Strongs Con Bible diterjemahkan an expected end atau akhir yang diharapkan atau akhir dengan penghargaan. Di dalam Amplified Bible (AMP) diterjemahkan to give you hope in your your final outcome atau untuk memberi harapan pada hasil akhir. ${ }^{29}$ Jadi, Allah berjanji akan memelihara umat-Nya walaupun bangsa Israel masih dalam

\footnotetext{
${ }^{26}$ Thomas Gordon, Mengajar Anak Berdisiplin Diri di Rumah dan di Sekolah. (Jakarta: PT Gramedia Pustaka Utama, 1996),3

${ }^{27}$ Yohanis Luni Tumanan, Disiplin Gereja Berdasarkan Injil Matius 18:15-17 Dan Implementasinya Dalam gereja Masa Kini, (Jurnal Jeffray: https: //ojs.sttjaffray.ac.id/JJV71/ article /view/231/pdf_136)

${ }^{28}$ Tjaard G Hommes dan Gerrit E. Singgih, Teologi dan Praksis Pastoral(Yogyakarta: Kanisius, 1992), 133.

${ }^{29}$ Djone Georges Nicolas, Penderitaan: analisa Yeremia 29:11dan relevansinya bagi orang percaya ditengah Krisis Pandemi Covid -19. (Jurnal syantax Admiration Vol.2 No. 2 Feb 2021 http://jurnal syntax admiration.com/ index .php/jurnal/article/view/177/278)
} 
pembuangan. Hal itu menimbulkan sikap penuh pengharapan dari umat Tuhan sehingga umat Tuhan tidak mudah menyerah apapun yang terjadi.

Seseorang yang sudah memiliki pertahanan iman yang teguh harus merencanakan kehidupannya dengan baik. Pandemi covid-19 tidak menjadikan rencana hidupnya terhalang tetapi tetap berjalan sesuai dengan Firman Tuhan. Walaupun Allah yang berdaulat memiliki otoritas untuk memutuskan sesuatu tetapi sebagai orang percaya yang diberikan kemampuan untuk merencanakan maka kita harus membuat rencana yang matang. "Di dalam kitab Lukas dijelaskan kalau ada orang yang mau membangun rumah maka orang itu harus memiliki perencanaan yang matang dan jika ada orang yang mau berperang harus memiliki perencanaan yang baik supaya berhasil dengan baik dan tidak mengecewakan"30. Perencanaan yang matang menjadikan kehidupan sesuai dengan arah Firman Tuhan. Arah yang baik membuat semua energi dapat dituangkan dengan fokus. Beriman teguh terjadi kalau seseorang harus diberikan teladan dan pengajaran Firman setiap hari. Orang tua harus merencanakan dan mengevaluasi iman anak-anak. Seseorang yang terbiasa untuk melakukan sesuatu sesuai dengan Firman maka orang itu akan memiliki iman yang teguh. Untuk itu, orang tua harus mengajar anak-anaknya melakukan secara berkelanjutan firman Tuhan yang sudah diajarkan kepada mereka. Iman yang teguh pasti menghasilkan kesabaran atas segala persoalan dan tantangan. Jadi, kesabaran ditunjukkan dengan sikap orang percaya yang beriman teguh sebagai perisai terhadap pencobaan supaya dapat dengan leluasa merencanakan kehidupan sesuai dengan arah Firman Tuhan.

Ketiga, Menunggu Waktu Tuhan dalam Doa. Yohanes berkata mintalah apa saja yang menunjukkan hubungan antara Tuhan dan orang percaya. Di dalam Doa kita harus menunggu waktu Tuhan dalam menjawab doa kita. Kesabaran merupakan bentuk perwujudan iman kita terhadap jawaban Tuhan sesuai dengan waktu Tuhan. Daniel Sutoyo berkata bahwa "waktu" dalam bahasa aslinya berasal dari kata kronos dan kairos dimana kronos menunjukkan urutan waktu dan kairos menunjukkan kesempatan. Tuhan selalu memberikan kesempatan yang terbaik dalam setiap rentetan waktu yang ada, untuk itu kita harus tetap sabar menunggu waktunya Tuhan". ${ }^{31}$ Tetapi kesabaran bukan menunggu dengan pasif seperti yang dikatakan oleh penulis Ibrani kita harus melihat dan meneladani saksi iman dengan menanggalkan dosa dan tetap taat dalam perlombaan iman". "Teks ini diawali kata karena itu mengingatkan kita supaya kita memperhatikan saksi-saksi secara aktif berlomba seperti olahraga Romawi, yang sedang berlomba di amphitheater yang memperoleh kemenangan"32 Jadi, dengan aktif para saksi iman itu menjalani kehidupannya dengan sabar walaupun ada tantangan. Tetap menunggu

\footnotetext{
${ }^{30}$ Gidion, Profesionalitas Layanan Gereja, Jurnal teologi dan pengembangan pelayanan, https://core.ac.uk/download/ pdf/285984839.pdf

${ }^{31}$ Daniel Sutoyo, Sebagai Golden Moment Orang Percaya (EPIGRAPHE: Jurnal Teologi dan Pelayanan Kristiani; Vol2, No. 1 (Mei 2018).

${ }^{32}$ Candara Gunawan, Bertekun dalam Iman (Jakarta: Jurnal amanat Agung, https:// ojs.sttaa. ac.id/index.php/JAA/article/view/301.
} 
waktunya Tuhan walaupun ada kesukaran karena percaya akan waktu Allah yang terbaik.

Tuhan selalu berjalan dalam sebuah proses sampai matang. Kesabaran membutuhkan waktu dalam ujiannya. Allah yang menguatkan kita dalam menanggung penderitaan dengan sabar, pencobaan itu cara Allah untuk memurnikan iman kita dan karakter kesabaran kita. Kita harus taat dalam kedaulatan Allah dalam menghadapi kejahatan orang lain, mereka menipu untuk kesuksesan hidupnya. Kita harus sabar karena kedatangan Tuhan segera, Dia memberikan kebaikan kepada kita yang selalu mencari Dia. Jadi, kesabaran ditunjukkan dengan kesiapan kita menunggu waktu Tuhan dalam doa walaupun di dalam proses ada pembentukan dari pencobaan-pencobaan yang dihadapi.

Keempat, Berserah Penuh Kepada Tuhan. Yohanes menyatakan bahwa, "buah akan semakin lebat pada saat kita siap dibersihkan oleh Firman Tuhan. Menurut Hendriksen bahwa pembersihan ranting menunjukkan pembenaran dan pengudusan bagi orang percaya sampai segambar dengan Allah ${ }^{33}$. Menurut Pulpit membersihkan ranting di pokok anggur lewat firman dan juga penderitaan dan kesulitan hidup."34 Untuk itu, kita harus berserah penuh kepada Tuhan supaya nilai kesabaran semakin bertumbuh dalam kita. ${ }^{35}$ Berserah penuh kepada Tuhan untuk Tuhan bentuk dan bersihkan adalah ditekankan sekali saat kita tinggal di dalam Yesus.

Pandemi covid-19 ini sudah menjadi tantangan yang sungguh sulit dihadapi keluarga-keluarga saat ini sehingga harus ada kemampuan untuk tetap kuat untuk mencapai cita-cita anak-anak dalam keluarga. Nilai kesabaran dalam hal ini adalah nilai berserah diri kepada Tuhan yang memiliki aspek daya juang artinya anak-anak dalam keluarga harus memiliki kekuatan dalam mencapai cita-citanya. "Orang tua yang memiliki daya juang tinggi menjadi teladan bagi anak-anak dalam berjuang untuk mencapai cita-citanya, jadi ada hubungan positif antara daya juang orang tua dengan anak-anak dalam mencapai cita-citanya." ${ }^{36}$ Nilai kesabaran ditunjukkan dengan sikap berserah diri dengan daya juang yang tinggi yang diteladankan oleh orang tua kepada anak.

Berserah diri kepada Tuhan juga ditunjukkan dengan aspek toleransi terhadap stress yang artinya seorang anggota keluarga dapat mengatasi stress yang mereka hadapi untuk menjalani kehidupan dalam masa pandemi ini. "Stress dapat muncul dalam tuntutan dan persoalan kehidupan bagi anak, sehingga anak harus diajarkan nilai kesabaran supaya dia tidak hidup kekanak-kanakan". ${ }^{37}$

\footnotetext{
${ }^{33}$ William Hendriksen, The Gospel of John, (Pennsylvania: The Banner , 1982) 89

${ }^{34}$ The Pulpit Commentary, e-Sword. 277),

${ }^{35}$ Barnes' Notes, 338

${ }^{36}$ Benedictus Aditya Gunawan, Hubungan Antara Keberfungsian Keluarga dengan Self-Regulated Learning Pada Siswa yang Tinggal di Asrama, (Jurnal PI)

${ }^{37}$ Seta Yovian Aryono, "Hubungan antara Adversity Quotient dan Kematangan Emosi dengan Toleransi terhadap Stres pada Mahasiswa Pecinta Alam Universitas Sebelas Maret” (UNS, 2015)
} 
Aspek lain dari berserah diri kepada Tuhan adalah kemampuan belajar dari kegagalan artinya bagaimana anak-anak memperbaiki sesuatu dari kegagalan karena ada tantangan supaya kehidupan dan cita-cita tercapai dengan baik. ${ }^{38}$ Selain itu, berserah diri kepada Tuhan adalah menerima masukan dari orang lain untuk mencapai hal yang positif. Jika banyak nasehat maka keputusan lebih baik. Tuhan berdaulat atas hidup kita, walaupun kita sudah berusaha semaksimal mungkin. Dengan menyerahkan diri sepenuhnya kepada-Nya akan terasa ringan dalam menjalankan hidup dan sehat secara rohani. Ujian sejati dari kesabaran terjadi ketika hak-hak kita diambil. Seseorang yang berserah diri kepada Tuhan ditunjukkan dengan tindakan tetap bersyukur, berusaha memahami rencana dan tujuan Tuhan dan meyakini janji Tuhan bahwa ia akan tetap bekerja dalam kehidupan kita.

Jadi, nilai kesabaran ditunjukkan pada saat kita berserah penuh kepada Tuhan, memiliki kematangan emosional, tetap bangkit dari kegagalan dan mampu menerima nasehat orang lain.

\section{Menanamkan Nilai Kesabaran di dalam Keluarga}

Sproul dalam bukunya "Kebenaran-Kebenaran Dasar Iman Kristen" menjelaskan, "cara orang tua dalam menanamkan nilai-nilai kebenaran diantaranya nilai kesabaran di dalam diri seseorang pada saat seseorang sudah tinggal di dalam Kristus dengan cara menjadi teladan dan mengajar secara verbal". ${ }^{39}$ Berdasarkan buku tersebut maka nilai kesabaran yang sudah kita temukan di dalam Firman dan buku-buku rohani yang lain harus ditanamkan kepada anggota keluarga. Keluarga merupakan lembaga terkecil dalam masyarakat yang terdiri dari suami, isteri dan anak-anak. Keluarga memiliki tanggung jawab masing-masing untuk membangun segala sesuatu demi kemajuan keluarga tersebut. Pendidikan pertama yang ditemukan seorang anak yang baru lahir ada di dalam keluarga. Anak-anak memperoleh dasar keterampilan (sensormotorik), dasar-dasar kecerdasan (bahasa, alam pikiran), dan dasar nilai hidup (agama, adat, tata kelakuan) di dalam keluarga. Menurut Gunarsa, "perkembangan seorang anak ada di bawah pengaruh keluarga anak tersebut" 40 Orang tua mendidik anak-anak mereka nilai-nilai Kristiani sehingga pada saat mereka dewasa mereka akan hidup sesuai dengan nilai-nilai itu. ${ }^{41}$

Menurut Tjandrarini, sedikitnya ada delapan fungsi dari keluarga yang meliputi: "fungsi pengaturan seksual, fungsi reproduksi, fungsi perlindungan dan pemeliharaan, fungsi pendidikan keluarga, fungsi sosialisasi, fungsi afeksi dan rekreasi, fungsi ekonomis, fungsi status sosial". ${ }^{42}$ Untuk menanamkan nilai kesabaran maka fungsi

\footnotetext{
${ }^{38}$ Mohamad Iksan, "Dukungan Sosial Pada Prestasi Dan Faktor Penyebab Kegagalan Siswa SMP Dan SMA”, (UIN, 2014)

${ }^{39}$ RC.Sproul, Kebenaran-Kebenaran Dasar Iman, (Malang: SAAT, 2018), 131

${ }^{40}$ Maurice Eminyan, SJ, Teologi Keluarga, (Yogyakarta: Kanisius, 2001), 157.

${ }^{41}$ Ibid, 233

${ }^{42}$ Kristiana Tjandrarini, Konseling Keluarga, (Salatiga: WSP, 2014), 7.
} 
pendidikan keluarga harus dijalankan di dalam keluarga orang percaya. Menanamkan nilai kesabaran bagi anggota keluarga harus terjadi melalui interaksi antara anggota keluarga. Interaksi seorang anak untuk belajar nilai kesabaran terdiri dari dua yaitu interaksi primer dan sekunder. ${ }^{43}$ Interaksi primer lewat keteladanan orang tua dan interaksi sekunder lewat pelajaran agama Kristen yang diberikan orang tua.

Pertama, Memberikan Keteladanan. Menanamkan nilai kesabaran kepada anggota keluarga yang lain khususnya anak-anak orang tua harus memiliki interaksi primer yaitu keteladanan kepada anak-anak. Orang tua menjalani kehidupannya secara alami dengan sabar dan menjadi teladan bagi anak-anak sehingga anak-anak juga menjalankan nilai kesabarannya dalam hidupnya. ${ }^{44}$ Max Weber menyatakan bahwa, "tindakan keteladanan seseorang akan berpengaruh positif dari situasi tertentu" 45 Orang tua dalam interaksinya dengan anak-anak harus memberi pengaruh positif lewat keteladanannya kepada anak-anaknya. Dalam mengajar anak-anak mereka orang tua juga harus menjalin hubungan yang dekat dengan anak-anak mereka supaya lewat hubungan itu anak-anak semakin mengenal nilai kesabaran dalam orang tua mereka. ${ }^{46}$

Orang tua melakukan perilaku sabar sebagai cerminan seorang Kristen, sabar antri di jalan, sabar terhadap orang yang lebih muda, yang mana hal-hal ini dengan sendirinya akan diteladani anak-anak kita. Fungsi pendidikan keluarga merupakan fokus dalam penelitian ini karena nilai kesabaran akan diterima anak-anak kita dengan melihat teladan dan ajaran orang tuanya. Yesus menjadi teladan dalam menanamkan nilai kesabaran kepada murid-murid-Nya. Menurut Tomatala, "Yesus sabar terhadap orang berdosa sehingga Dia belum datang sampai hari ini, karena Yesus tidak mau ada yang binasa". ${ }^{47}$ Kesabaran selalu memikirkan orang lain supaya mencapai kesuksesan yang terbaik. "Orang tua juga harus selalu memiliki interaksi dengan akan-anak supaya anak-

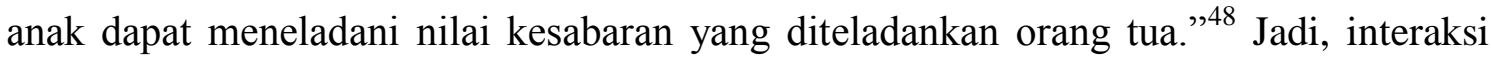
orang tua dan anak akan menanamkan nilai kesabaran kepada anak sebagai interaksi primer yang menjadi dasar pendidikan secara verbal.

Kedua, Mendidik Anak Dalam Firman. Interaksi Primer dimana orang tua meneladankan nilai kesabaran kepada anak menjadi dasar interaksi sekunder yaitu mendidik anak dalam Firman. Nuhamara mendefinisikan pendidikan sebagai usaha yang sadar untuk menanamkan nilai-nilai kepada orang yang dipimpin khususnya tentang agama ${ }^{49}$ Tujuan menanamkan nilai kesabaran kepada anggota keluarga supaya

${ }^{43}$ Hetherington, Child Psychology, (New York: Mc. Graw Hill Book Company, 1986). 224

${ }^{44}$ Nainggolan, J,M. Strategi PAKn, (Jabar : Penerbit Generasi Info Media,2008), 39-42.

${ }^{45}$ Paul D Johnson, Teori Sosiologi , (Jakarta: Gramedia, 1986), 216

${ }^{46}$ Desi Sianipar, Analisis Implementasi PAK Keluarga Di Gereja Sidang Jemaat Allah, (GSJA ( Kabupaten Baribo Timur Kalimantan Tengah, Jurnal Pendidikan Agama Kristen, vol.2, No.2 Oktober 2018, 41,42)

${ }^{47}$ Yakob Tomatala, Teologi kontekstualisasi, (Malang:Gandum Mas, 1996), 56

${ }^{48}$ Hurlock, E, Perkembangan Anak Jilid 2, Edisi 6, (Jakarta: Erlangga, 1999).

${ }^{49}$ Thomas H. Groome, Christian Religious Education, (Jakarta: BPK Gunung Mulia, 2010), 31 
anggota keluarga memiliki nilai kesabaran (believing), perasaan yang sabar (trusting) dan tindakan yang sabar (doing). Hal itu berproses di dalam keluarga".50

Perjanjian Lama sangat menekankan pendidikan di dalam keluarga. "Kata pendidikan di dalam bahasa Ibrani adalah khenokh yang mengambarkan seorang guru yang memberikan pengajaran secara berkelanjutan kepada murid-Nya." ${ }^{, 51}$ Penulis Amsal berkata "Didiklah orang muda menurut jalan yang patut baginya, maka pada masa tuanyapun ia tidak akan menyimpang dari pada jalan itu." ${ }^{, 52}$ Orang Yahudi dalam menanamkan nilai kepada anak-anak mereka melakukannya secara berkesinambungan baik waktu berjalan, waktu berbaring, waktu duduk. Dua teks yang selalu menjadi dasar pendidikan agama Kristen di Perjanjian Lama adalah Ulangan 6:1-7 dan Ulangan 11:1819. Kedua nats ini memperlihatkan bahwa Perjanjian Lama menjelaskan bahwa rumah dalam arti keluarga selalu dilihat sebagai tempat utama untuk memberikan pendidikan. Pendidikan di Yahudi lebih kepada pengajaran Taurat. Sedangkan pendidikan secara umum pada umumnya dilakukan di dalam Keluarga. ${ }^{53}$ Allah memanggil orang tua untuk menjadi teladan dan mengajarkan nilai kesabaran bagi anak-anak mereka. ${ }^{54}$

Jadi, menanamkan nilai kesabaran harus dilakukan oleh orang tua dengan setia secara berulang-ulang membicarakan dan mengajarkan nilai kesabaran tersebut agar nilai itu masuk ke hati mereka dan mengerti serta melakukannya dalam kehidupan sehari-hari.

Menanamkan nilai kesabaran dengan cara mendidik anggota keluarga dengan Firman Tuhan. Kata "mendidik" dalam bahasa Yunai adalah ektrepho artinya seorang guru akan memberikan makanan rohani kepada muridnya. ${ }^{55}$ Nilai kesabaran ditanamkan kepada anak yang menurut Glenn Clark seperti surat dalam amplop tertutup. Untuk itu, orang tua harus menuliskan dalam surat itu nilai-nilai kristiani, khususnya nilai kesabaran. ${ }^{56}$ Materi pendidikan yang diberikan kepada anak-anak adalah ajaran Tuhan khususnya nilai kesabaran. Proses tertanamnya nilai kesabaran dalam diri seorang anak melalui tiga tahapan yatu: persepsi, interpretasi atau definisi, dan respon. ${ }^{57}$ Berdasarkan tiga proses tahapan ini dalam diri anak akan terbentuk nilai kesabaran yang dipelajarinya dalam pendidikan agama Kristen di rumah mereka.

\footnotetext{
${ }^{50}$ Komisi Internasional, Pedoman Promotor Keadilan, Perdamaian, dan Keutuhan Ciptaan, (Yogyakarta: Kanisius, 2001), 21.

${ }^{51}$ Lawrence O. Richard, Pelayanan Anak, (Bandung: YKH, 2007), 29-30

${ }^{52}$ Amsal 22:6

${ }^{53}$ Yohanes, PAK PL, BIA': Jurnal Teologi dan Pendidikan Kristen Kontekstual 2, no.2 (2019):148

${ }^{54}$ Supriyono, Pendidikan Keluarga dalam Persfektif Masa Kini, (Jakarta: Sekretariat Direktorat Jenderal Pendidikan Anak Usia Dini dan Pendidikan Masyarakat, 2015), 13

${ }^{55}$ Leksikon Yunani (1625)

${ }^{56}$ Larry, Keluarga Bahagia, (Semarang: YPB, 1992), 63

${ }^{57}$ T.O, Ihromi, Sosiologi Kekeluargaan, (Jakarta: YOI, 1999), 30

${ }^{57}$ Singgih Gunarsa, Psikologi Perkembangan, (Jakarta: BPK GM, 1986), 6.
} 


\section{Kesimpulan}

Penelitian ini didasarkan kepada Injil Yohanes 15:1-10 untuk menemukan aspekaspek yang menghasilkan nilai kesabaran dan cara menanamkan kesabaran tersebut. Ditemukan nilai-nilai kesabaran setelah diadakan analisa mendalam terhadap nas adalah: Pertama, nilai kesabaran akan lahir pada saat seseorang berakar pada Firman Tuhan. Seseorang yang berakar dalam Firman pada saat seseorang akan membaca, mempelajari, menghafal, merenungkan dan menerapkan Firman Tuhan secara konsisten dimasa pandemi covid-19 ini. Kedua, nilai kesabaran lahir pada saat seseorang taat kepada Firman Tuhan sehingga orang itu memiliki iman yang teguh sebagai prisai terhadap pencobaan supaya dapat dengan leluasa merencanakan kehidupan sesuai dengan arah Firman Tuhan. Ketiga, nilai kesabaran lahir pada saat seseorang berserah penuh kepada Tuhan di dalam doa, memiliki kematangan emosional, tetap bangkit dari kegagalan dan mampu menerima nasehat orang lain. Keempat, nilai kesabaran lahir pada saat kita berserah penuh kepada Tuhan siap dibentuk oleh Tuhan. Cara orang tua dalam menanamkan nilai-nilai kebenaran diantaranya nilai kesabaran di dalam diri seseorang pada saat seseorang sudah tinggal di dalam Kristus dengan cara menjadi teladan dan mengajar secara verbal. Untuk itu menanamkan nilai kesabaran ini oleh orang tua dengan cara menjadi teladan kepada anak-anak. Orang tua harus dengan disiplin mengajarkan Fiman Tuhan dengan cara membaca, mempelajari, menghafal dan merenungkan serta menerapkan. Jadi, menanamkan nilai kesabaran pada anak-anak terjadi dalam interaksi di dalam keluarga dalam sebuah persekutuan. Persekutuan ini harus diusahakan dan disengaja secara berulang-ulang karena hal itu sangat penting dalam menanamkan nilai kesabaran. Anak-anak akan menyesuaikan diri terhadap nilai kesabaran yang dijalankan orang tua dan hidup dalam kesabaran setelah mereka mendapat pendidikan akan nilai kesabaran tersebut.

\section{Referensi}

Ensiklopedi Alkitab Masa Kini Jilid II, Jakarta: Yayasan Komunikasi Bina Kasih, 2008

Alkitab, LAI, 2014

Anastasia Tamara, Mau Pandemi Usai? Ketahui Pentingnya Gerakan 5M COVID-19, https://www.klikdokter.com/info-sehat/read/3644583/mau-pandemi-usaiketahui-pentingnya-gerakan-5m-covid-19

Aryono Seta Yovian, "Hubungan antara Adversity Quotient dan Kematangan Emosi dengan Toleransi terhadap Stres pada Mahasiswa Pecinta Alam Universitas Sebelas Maret” (Psikologi.Fk.Uns :https://jurnalwacana. psikologi.fk.uns.ac.id/ index. Php /wacana /article/view/108)

Budiman Aditya, Update Covid-19 per 7 Maret 2021https:// nasional. tempo. co/read/ 1439762/update-covid-19-per-7-maret-2021-kasus-positifbertambah-5-826 
Candara, Bertekun dalam Iman(Jakarta: Jurnal Amanat Agung, https:// ojs.sttaa. ac.id/index.php/JAA/article/view/301.

Christenson, Larry Keluarga Kristen., Semarang: Yayasan Persekutuan Betania, 1992.

Damarwan Seri, Nilai Kesempurnaan Kristen Dalam Kitab Ibrani, Jurnal Teologi Sanctum Domine, (Article Text-97-1-10-20191212.pdf)

Eminyan, SJ.,Maurice, Teologi Keluarga,Yogyakarta: Kanisius, 2001

Groome, Thomas H.,Christian Religious Education, Jakarta: BPK Gunung Mulia, 2010.

Gunarsa, Singgih dan Ny. Singgih Gunarsa., Psikologi perkembangan Anak dan Remaja, Jakarta: BPK Gunung Mulia, 1986.

Hadinoto, N. K. Atmadja., Dialog Dan Edukasi, Jakarta: BPK Gunung Mulia, 2000.

Hartono Handreas, Membentuk Karakter Kristen Pada Anak Keluarga Kristen, Jurnal Teologi dan Pendidikan Agama Kristen KURIOS, Vol. 2, No.1, Oktober 2014 (62-69) ISSN 2406-8306.

Hetherington.,Child Psychology, A Contempary Viewpoint 3rd edition, New York: Mc. Graw Hill Book Company, 1986.

Homrighausen \&I. H. Enklaar., Pendidikan Agama Kristen, Jakarta: BPK Gunung Mulia, 1984.

Hurlock, E., Perkembangan Anak Jilid 2, Edisi 6, Jakarta: Erlangga, 1999.

Ihromi, T.O, Bunga Rampai Sosiologi Keluarga, Jakarta: Yayasan Obor Indonesia, 1999.

Iksan Mohamad, "Dukungan Sosial Pada Prestasi Dan Faktor Penyebab Kegagalan Siswa SMP Dan SMA”, (Fakultas Psikologi Universitas Islam Negeri (UIN) http://psikologi.uin-malang.ac.id/wp-content/uploads/2014/03)

Johnson Paul D, Teori Sosiologi Klasik Dan Modern Jilid 2, Jakarta: Gramedia, 1986

Krismantyo Susanta, Tradisi Pendidikan Iman Anak Dalam Perjanjian Lama, BIA': Jurnal Teologidan Pendidikan Kristen Kontekstual 2, no.2 (2019):148

Moleong Lexy. J., Metodologi Penelitian Kualitatif,Bandung: Remaja Rosdakarya, 2001

Nainggolan, J,M. Strategi Pendidikan Agama Kristen, Jabar : Penerbit generasi info media,2008.

Nicolas Djone Georges, Penderitaan: analisa Yeremia 29:11dan relevansinya bagi orang percaya ditengah Krisis Pandemi Covid -19. (Jurnal syantax Admiration Vol.2 No. 2 Feb 2021 http://jurnal syntax admiration.com/ index .php/jurnal/article/view/177/278)

Nuhamara, Daniel., Pembimbing PAK, Bandung: Jurnal Info Media, 2017

Peraturan Menteri Kesehatan Republik Indonesia Nomor 10 Tahun 2021

Sianipar, Desi., Analisis implementasi PAK keluarga di gereja sidang Jemaat Allah GSJA Kabupaten Baribo Timur Kalimantan tengah, Jurnal Pendidikan Agama Kristen, vol.2, No.2 Oktober 2018, 41,42 
Simamora May Rauli, Johanes Waldes Hasugian, Penanaman Nilai-nilai Kristiani bagi Ketahanan Keluarga di Era Disrupsi (Jurnal: Regula Fideil Jurnal pendidikan Agama Kristen, 2020), 13-24

Sobur, Alex., Pendidikan Anak Dalam Keluarga, Jakarta: BPK Gunung Mulia, 1987.

Sproul, RC, Kebenaran-Kebenaran Dasar Iman, Malang: SAAT, 2018

Subagiyo, Joko., Metode Penelitian dalam Teori dan Praktek, Jakarta: Rineka Cipta, 2004.

Supriyono., Pendidikan Keluarga dalam Persfektif Masa Kini, Jakarta: Sekretariat Direktorat Jenderal Pendidikan Anak Usia Dini dan Pendidikan Masyarakat, 2015

Sutoyo, Daniel, Sebagai Golden MomentOrang Percaya (EPIGRAPHE: Jurnal Teologi dan Pelayanan Kristiani; Vol2, No. 1 (Mei 2018).

Tjandrarini, Kristiana., Bimbingan Konseling Keluarga, Salatiga: Widya Sari Press, 2014.

Tomatala Yakob, Teologi Kontekstualisasi, Malang: Gandum Mas, 1996

Trobisch ,Walter., I Married Youterj. Hadiwinoto dan Susiloradeyo, Jakarta: BPK Gunung Mulia, 1973.

Tumanan Yohanis Luni, Disiplin Gereja Berdasarkan Injil Matius 18:15-17 Dan Implementasinya Dalam Gereja Masa Kini, (Jurnal Jaffray: https: //ojs.sttjaffray.ac.id/JJV71/ article /view/231/pdf_136) 